Kommentar

\title{
Hva er en god NOU?
}

Cathrine Holst

\section{cathrine.holst@sosgeo.uio.no}

Professor

Institutt for sosiologi og samfunnsgeografi og ARENA Senter for europaforskning, Universitetet i Oslo

Ingress: Det ligger mye makt i makten til å utrede. Vi bør bry oss mer om hvem vi gir i oppdrag å utrede offentlig politikk - og hvordan utrederne våre leverer. For å kunne si om norsk utredningsvesen holder mål eller ikke, må vi ha en idé om hva en "god" utredning er. Denne kommentaren drøfter ulike vurderingskriterier. Én konklusjon er at viktige kriterier, som at gode utredninger skal være "kunnskapsbaserte» eller "partssammensatte», gir stort rom for fortolkning. En annen konklusjon er at ulike vesentlige kriterier kan dra $i$ ulik lei. En god utredning skal være tro mot mandatet og strekke det ved behov; være nyskapende og appellere til etablerte interesser; sikre innsyn og gi utrederne ro til å utrede; trygge demokratisk forankring og bygge på råd fra ekspertene som best kan saksfeltet.

I et demokrati er det de folkevalgte som skal bestemme politikken, men det kan være en fordel at samfunnsmessige problemer og politikken som settes ut $\mathrm{i}$ livet for å bøte på dem er utredet på forhånd. Mye utredning i Norge gjøres internt i departementer og direktorater, og av institusjoner som Norges Bank og Statistisk Sentralbyrå. Norges forskningsråd har også en omfattende portefølje av anvendte forskningsprogrammer, og det finnes en stor sektor av anvendte forskningsinstitutter. Mye instituttforskning er offentlig finansiert og inngår som grunnlag for politikkutforming. Også tunge interesseorganisasjoner som LO og NHO bedriver utredningsarbeid rettet inn mot myndighetene. 
Offentlige utvalg er med andre ord ikke den eneste utredningsinstitusjonen i Norge, men de har vært og er sentrale. Mange av disse utvalgene, unntaksvis nedsatt av Stortinget, men som regel av Regjering og departement, leverer rapporter som kommer ut i serien Norges offentlige utredninger (NOU). Fra NOU-seriens oppstart i 1972 til og med 2016 har i alt 1125 utvalg vært i arbeid og levert utredninger. ${ }^{1}$ I samme periode har 9953 personer - fremfor alt byråkrater, forskere, organisasjonsrepresentanter og politikere - vært involvert som utvalgsmedlemmer. Utallige høringsuttalelser er skrevet $i$ årenes I $\varnothing p$ av kommuner, etater, organisasjoner, bedrifter og enkeltpersoner. Ikke alle utvalg får gjennomslag for sin virkelighetsbeskrivelse og sine forslag, men mange av dem er med og setter dagsorden, og, om enn i varierende grad, ender utvalgsforslag opp som gjeldende norsk lov og politikk. Dette er bakgrunnen for at samfunnsforskere har betraktet utredningsutvalg som en hovedpilar i den norske styringsmodellen.

\section{Usynlig makt}

Det heter gjerne at grunnloven angir maktfordelingen i Norge, men NOUsystemet kan være eksempel på en institusjon der mye politisk makt er samlet, uten at dette fremgår av det formelle konstitusjonelle kartet. Når elevene lærer om demokrati og politikk på skolen, lærer de lite eller ingenting om utredningsvesenet vårt. Rikspolitikerne blir nok etter hvert god kjent med NOUene, men snakker ikke så mye om dem. Referanser til «utredninger» skaper ikke engasjement og mobiliserer ikke velgere - og politikere vil ta æren for gode forslag selv, og klebe dårlige forslag til opposisjonen. Hva et «utvalg» måtte ha ment, er ikke alltid så relevant. Også journalistikken fokuserer gjerne mer på det politiske spillet i og mellom Storting og Regjering, og på debatter og utspill i mediene selv, enn på det som har skjedd forut - løpet som er lagt gjennom saksforberedelser og utredning.

Dette henger selvsagt sammen med at dette løpet ikke er så lett å få klarlagt. Forvaltning og Regjering er gitt et betydelig rom for skjønn, og avveininger rundt mandater, utvalgssammensetning og veien videre for avleverte rapporter skjer typisk ikke i all offentlighet. En gjennomsnittlig norsk offentlig utredning kan også være langdryg og tunglest. Det vil ofte være vanskelig for dem som ikke er på innsiden av sakskomplekset å spore de brennbare politiske spørsmålene bak ekspertdiskurs, tekniske vurderinger og reguleringsdetaljer.

Vi burde imidlertid brydd oss mer om NOU-ene. Offentlige utredninger kan legge avgjørende premisser for politiske prioriteringer, og i neste omgang 
fordelingen av privilegier og byrder. Vi bør derfor være opptatt av - og når det trengs, kritiske til - hvem som lager NOU'ene, oppdragene disse får, hvem som definerer oppdraget, og hva de som får oppdragene faktisk leverer. Kort sagt bør vi oftere spørre, ikke bare om en sak er utredet, men om den er godt utredet.

\section{Kunnskapsbasert - hva betyr det?}

Svaret på det siste avhenger naturlig nok av hva vi tenker at en god utredning skal være. Det vil være en overdrivelse å si at vi i Norge i dag har en «debatt» om dette. Ulike kriterier for "gode» - og ikke fullt så gode - NOU-er, sirkulerer likefullt, i meningsdanning, blant politiske aktører, i styringsverk og forskning.

Et gjengs krav mange stiller til en god utredningsrapport er at den er kunnskapsbasert. Det har over tid blitt stadig flere forskere blant medlemmer og ledere av NOU-utvalg, mens andelen organisasjonsrepresentanter og politikere er synkende. Dette reflekterer en tendens der det i tiltagende grad settes likhetstegn mellom «kunnskap» og "vitenskap», og til og med «evidens»: Analyser og politikkforslag skal fortrinnsvis forankres i forskning basert på «store data» og med eksperimentell design.

Et ferskt eksempel på en utredning som leverer rigorøst ut fra et slikt kriterium er NOU 2019: 3 Nye sjanser - bedre læring. Kjønnsforskjeller i

skoleprestasjoner og utdanningsløp (Stoltenberg-utvalget). I høringsrunden er imidlertid flere kritiske til et kunnskapsbegrepet denne rapporten baserer seg på. Forskningsmiljøer etterlyser skole- og likestillingsforskning fra andre fagtradisjoner og ut fra et bredere sett av metodiske tilnærminger.

Lærerorganisasjonene er kritiske til at deres «profesjonskunnskap» og «erfaringskunnskap» ikke er tatt høyde for av utvalget, mens NHO kritiserer utvalget for å overse «partenes» kunnskap. ${ }^{2}$

\section{$\varnothing$ konomene kommer}

Tilsvarende strider om hvem sin og hva slags kunnskap har vi også sett rundt andre utvalg. Debattene om økonomenes rolle er en gjenganger. Økonomene har lenge dominert utvalg nedsatt av Finansdepartementet, men andelen $\varnothing$ konomer i NOU-utvalg på andre politikkfelt som miljø, helse og utdanning er også stigende. Noen vil hevde at dette gir bedre utredninger, ikke minst sett $\mathrm{i}$ lys av krav om at politiske forslag skal underlegges «samfunns $\varnothing$ konomisk konsekvensanalyse». ${ }^{3}$ Andre mener at $\varnothing$ konomenes problemforståelse og verktøykasse gis for stor vekt, og etterlyser andre faggrupper. 
Det heter at politikken rettsliggjøres, men andelen jurister i NOU-ene har faktisk gått ned de siste årene. Dette bekymrer mange jurister som mener færre jurister kan svekke både reguleringskvalitet og rettsstatshensyn. Veksten i andelen $\varnothing$ konomer og andre samfunnsvitere blant NOU-medlemmer uroer også i teknologiske og medisinske fagmiljøer. Over tid er det blitt en lavere andel utvalgsmedlemmer med naturvitenskapelig fagbakgrunn, paradoksalt nok, vil noen si, i en situasjon der mange mener at politikk bør forankres sterkere $\mathrm{i}$ «evidens» og «hard vitenskap».

Men bildet er selvfølgelig ikke entydig - det er det aldri. I underkategorien av NOU-er som på reguleringsspråket kalles «lovutvalg» dominerer juristene fortsatt sterkt. Noen vil si for sterkt, for juridiske spørsmål vil alltid også berøre substansspørsmål som andre faggrupper enn juristene har mer peiling på. Selv har jeg i det siste sett nærmere på NOU-ene innenfor rusfeltet, ${ }^{4}$ og her er medisinerne tungt inne, i tillegg til juristene, mens presumptivt relevante faggrupper som sosiologer og kriminologer står svakere.

\section{Hva med humaniora?}

Professor i politisk historie Teemu Ryymin og kolleger ved Universitetet $\mathrm{i}$ Bergen etterlyser i boken Historie og politikk. Historiebruk i norsk politikkutforming etter 1945 (2017) en mer forskningsmessig tilnærming til historieskriving i NOU-ene. Dette burde tale for flere historikere i utvalg - de har vært få så langt. Andre igjen tenker at filosofene kan spille en rolle $\mathrm{i}$ politikkutforming. Filosofiprofessor i Oxford Jonathan Wolff skriver i boken Ethics and Public Policy (2019) om sine erfaringer fra utredningskommisjoner I Storbritannia. Filosofen kan potensielt ha en rolle, mener han; ikke i kraft av sin særlige innsikt i det godes idé, slik Platon så for seg filosofstyret $\mathrm{i}$ idealstaten, men i kraft av sin kompetanse i å avklare begreper og argumentasjon. Det er imidlertid få filosofer i offentlige utvalg, og generelt få humanister. De få gangene en NOU får skryt for å være særlig velskrevet - noe en god NOU definitivt burde være - sitter det ikke sjelden en humanist i utvalget eller i sekretariatet, for eksempel historieprofessorer, som Francis Sejersted, leder av NOU 1999: 27 «Ytringsfrihed bør finde Sted», eller Olav Njølstad i sekretariatet for 22. juli-kommisjonen.

Oppsummert kunne vi si at en god utredning ikke bare er kunnskapsbasert, men også har en adekvat sammensetning av disipliner. Hva som i ulike tilfeller vil være «adekvat», er det imidlertid ikke så lett å enes om. Generelt kan det være lettere å se at et faglig perspektiv mangler i etterkant, enn å enes om en 
optimal faglig miks på forhånd. I ettertid fremstår det for eksempel som påfallende at NOU2012: 14 Rapport fra 22. juli-kommisjonen, med sin bredside mot «ledelse» og "kultur» i norsk sentralforvaltning, ikke hadde en eneste forvaltningsforsker blant utvalgsmedlemmene. I månedene etter angrepet 22 . juli, hadde imidlertid de fleste, inkludert dem som satte ned Gjørvkommisjonen, mye annet å tenke på.

\section{Kunnskapsmessig pluralisme}

En tommelfingerregel kan kanskje være at ett-faglige utvalg bør unngås, med mindre særlige grunner taler for. Rene økonom- eller jurist-NOU-er bør i utgangspunktet være unntak. En annen tommelfingerregel kan være at utvalg ikke bør settes sammen for å omgå relevant og anerkjent faglig strid blant ekspertene i feltet. Kvaliteten på «kunnskapsbasering» styrkes av at ulike kompetente syn får brynes mot hverandre.

I tillegg kommer det selvsagt at ulike typer av forskning ofte vil inngå sentralt i den relevante kunnskapsbasen, men at forskning alene sjelden duger. NOU-er skal anbefale sektorrelevant politikk og regulering, og en god utredning vil typisk holde seg med gode byråkrater som «kan» feltet - det vil si som kjennersystemene som er, tekniske detaljer, tidligere politikk, reguleringsspor og implementeringsvilkår. Jeg har snakket med mange departementsfolk som mener at det alt i alt er de selv, og ikke forskerne, som kan mest om pensjon, trygd, miljøreguleringer og landbrukssubsidier her til lands. Det kan være rett nok, og er et argument for at det også bør sitte byråkrater rundt utvalgsbordet. Utvalgene kan imidlertid også fungere som kritiske korrektiver til ufunderte tatt for gitt-heter blant byråkratene, som allerede dominerer utvalgssekretariatene, og som har stor makt til å bestemme utvalgssammensetning og mandater, $\mathrm{i}$ mer eller mindre tett dialog med politisk ledelse.

Relevant kunnskap kan dessuten komme «nedenfra», fra praktikerne i feltet, sivilsamfunn, organisasjoner og sosiale bevegelser. I høringen etter Stoltenberg-utvalget etterlyste $\mathrm{NHO}$ «partenes» kompetanse, og tradisjonelt har arbeidslivets parter spilt en sentral rolle i NOU-ene. En viss avkorporativisering av utredningssystemet er imidlertid på gang, men arbeidslivets parter sitter fortsatt ofte i utvalg, og en del av de virkelige utvalgsrytterne i NOU-systemet - de som blir oppnevnt som utvalgsmedlemmer igjen og igjen - kommer fra LO og NHO. Generelt kan også profesjonsorganisasjoner stadig vekk sitte på høyrelevant sektor- og praktikerkunnskap, og de reagerer forståelig nok når de settes på sidelinjen. 
I et sivilsamfunnsperspektiv, kan det imidlertid være mange om beinet, og det vil gjerne være strid, også her, om hvem som har den beste og mest relevante ekspertisen eller «motekspertisen». For eksempel er miljøorganisasjoner ikke bare opptatt av selv å få en plass rundt bordet når NOU-er skal lages, men også av at miljøhensyn generelt skal vektes sterkere. Dette, vil de si, kan gjøres bedre av en miljøengasjert forsker eller av en miljøbyråkrat, enn av organisasjonsrepresentanter med «feil» ståsted, for eksempel fra LO eller NHO. Det pågående Rusreformutvalget har inkludert representanter fra brukerorganisasjoner ut fra en rimelig antagelse om at disse besitter vesentlig erfaringskunnskap. Strid er det likevel blitt, og kritikk har kommet fra brukerorganisasjoner som ikke sitter i utvalget og som mener at noen brukersynspunkter privilegeres fremfor andre.

\section{Mandatlojalitet - og mandatstrekk}

Det sier seg selv at utvalgssammensetning med henblikk på «kunnskapsbasering» ikke er noen perfekt vitenskap, og at vanskelige avveininger vil være regelen. Mandatet bør dessuten være relativt styrende. Noen mandater ber om generell forskningsstatus - her leverer gjerne forskerne best. Noen ber, enda mer avgrenset, om spesifikke typer av forskning, for eksempel bes Stoltenberg-utvalget særlig om å tilveiebringe forskning om «årsaker» og "kunnskapsoversikter» med relevans for «effektstudier». Det er klart dette måtte prege både sammensetningen av utvalget og rapportens utforming. Andre mandater innbyr til en bredere problemtilnærming og kunnskapsinnhenting, etterspør omforente ståsteder og virkelighetsforståelser mer enn «ny kunnskap», eller dreier seg fremfor alt om regulering og implementering. Slike bestillinger vil ikke rene forskerutvalg være godt rustet til å besvare.

Ulike typer av mandater kan være egnede; politikkutforming kan trenge utredninger av flere slag. Det vi bør være på vakt mot, er tendenser til at én utredningstype fortrenger andre. Det er for eksempel et problem hvis utvalgsmandater systematisk utformes så de omgår å etterspørre forskningen på feltet. Eller motsatt, hvis mandater gjennomgående formuleres på måter som ugyldiggjør relevant kunnskapsproduksjon, for eksempel på grunn av overdreven vekt på «evidensbasering».

En god utredning kan dessuten holde seg til mandatet, og samtidig strekke og utfordre det $-\mathrm{i}$ et visst monn. For eksempel bør en utredning som bes om å utrede $\varnothing$ konomiske og administrative konsekvenser, eller å anbefale på basis av 
"uendret ressursbruk», antageligvis tilstrebe å levere som bestilt. Det politiske ordskiftet og politikkutformingen i det lange løp er selvsagt avhengig av fritenkning, men kanskje ikke i statlig regi og underlagt departement og utredningsinstruks, og et utvalg som gir blanke $\mathrm{i}$ «konsekvenser» og «rammer», vil miste autoritet og legitimitet. Slik hensyn gjør samtidig utredningstekster mindre underholdende, og jeg har hørt det sagt at NOU-er er «kjedelige», men $i$ en viss forstand følger dette av det NOU-er er og skal være.

Det er likevel mye mandater ikke nødvendigvis uttrykkelig ber om, men som en god utredning gjerne bør levere, for eksempel diskusjon av usikkerhet rundt beregninger, og prinsipielle avveininger rundt mål, målprioritering og målkonflikter. De som leser en NOU bør kunne forvente å få en nøktern fremstilling av hva som er relativt sikker kunnskap og hva som er estimater og stridspunkter. De bør også kunne forvente åpenhet rundt normative premisser. Mer gjennomsiktige NOU-er på punkter som dette vil også bidra til å gjøre ekspertuenighet mer begripelig, for eksempel når NOU 2014: 13 og NOU 2018: 5 , kommer til helt motsatte konklusjoner om formueskatt.

\section{Kreativitet og gjennomslag}

Kanskje bør NOU-lesere også kunne forvente noe "nytt». En vellykket NOU er gjerne en som evner å formulere forslag som ikke alt lå i bordet og som «alle» alt hadde tenkt på. Et eksempel fra det siste kan være NOU 2017: 6 Offentlig støtte til barnefamiliene (Ellingsæter-utvalget). Utvalget foreslår å erstatte barnetrygd til alle med behovsprøvd barnetrygd i kombinasjon med gratis barnehager, og forankrer forslaget i et begrep om «universell» velferdsstat som vektlegger «universelle tjenester» like mye som «universelle ytelser».

Dette grepet er nyskapende, og var ikke gitt - og gjennomslaget har så langt uteblitt. Et suksesskriterium kan imidlertid ikke være maksimalt gjennomslag på kort sikt. Av og til må forslag modne - og tidene skifte. Forslaget i NOU 2011: 18 Struktur for likestilling (Skjeie-utvalget) om å gi

Diskrimineringsnemnda myndighet til å håndheve forbudet mot seksuell trakassering i likestillings- og diskrimineringsloven, ble først lagt i skuffen, for så - etter \#metoo - å bli vedtatt av Stortinget i juni 2019.

Og gjennomslag, i det minste over tid, er naturligvis ikke irrelevant. Her kan det igjen være et visst misforhold mellom hva offentligheten får med seg - for eksempel hvilke utredninger vi ofte ser henvist til i avisspaltene - og hva som skjer i det lange løp og bak kulissene. I den grad folk flest kjenner til NOU- 
ledere, vil det gjerne være ledere av medieprofilerte utredninger som Alexandra Gjørv (22. juli-kommisjonen), Grete Brochmann (Brochmann 1 og 2utvalgene) og Francis Sejersted (Ytringsfrihetskommisjonen). Men utredninger og utredere kan ha stor innflytelse i det stille. Sentrale skikkelser i NOUsystemet, for eksempel Inge Lorange Backer og Erling Selvig, begge jusprofessorer og gjengangere i utvalg og utvalgsledelse gjennom tiår, har først og fremst innsiderne hørt om.

\section{Demokrati og tillit - og mål i konflikt}

Det finnes politiske eliter, inkludert en «utvalgselite» - og kanskje er den for smal? Et godt utredningsvesen, vil mange si, skal ikke bare levere god kunnskap og godt politikk, men også oppfylle visse krav om inklusjon og åpenhet. Dette dreier seg om å skape tillit til utredningene og forankre dem i berørte miljøer, men i et demokrati har representasjon og deltagelse også verdi i seg selv. Krav om kjønnsbalanse og geografisk spredning i NOU-ene må ses i lys av dette. Sivilsamfunn kan nok bidra med verdifull «kunnskap» og «kompetanse», men når organisasjoner inkluderes i utredninger, dreier det seg også om representasjon av vesentlige samfunnsmessige verdier og interesser. Tilsvarende gjelder høringsrundene. De kan supplere et utilstrekkelig eller skjevt kunnskapsgrunnlag, men sikrer også forankring og demokratisk legitimitet.

Og motsatt, når det klages om for stramme høringsfrister, eller hvis organisasjonslivet føler seg utelatt når NOU-er som berører dem skal snekres, utfordrer dette NOU-ene som bestanddel i det norske demokratiet og i et politisk system som befolkningen så langt har hatt høy tillit til. En sterkere demokratisering av NOU-ene kan også tenkes langs andre spor. En del nyere utvalg har vært åpnere enn det som har vært vanlig. Det legges ut underlagsrapporter og møtereferater og arrangeres konsultasjonsmøter underveis, og det eksperimenteres med digitale plattformer. Et synspunkt som også er blitt luftet, er at NOU-systemet med fordel kan bli mindre konsensusorientert, og at terskelen blant utvalgsmedlemmer for å formulere dissenser $b \varnothing r$ være lavere. Bak dette synspunktet ligger demokratihensyn: Ulike stemmer bør komme frem og ikke gjemmes bak et minste felles multiplum.

«Mer demokrati» er generelt vanskelig å være mot, men NOU-systemet har ulike funksjoner, og alle gode ting går ikke alltid sømløst i hop. Det kan være vanskelig å utstyre et utvalg både med tilstrekkelig tung og mangfoldig forsknings- og reguleringskompetanse og samtidig gi plass til stort og smått av 
interessenter i sektoren. Kunnskapshensyn og inklusjonshensyn kan, kort sagt, dra i litt ulik lei. Utvalgsdeliberasjon bak lukkede dører strider med åpenhetsidealer, men kan også få stridende parter til å senke skuldrene og søke gode løsninger på tvers. Dissenser kan være forfriskende og fremme og skjerpe offentlig debatt, men utredninger med mange dissenser får en blekere signatur og kan miste tyngde i den videre politiske prosessen. Antagelsen om at partsdeltagelse og høy tillit alltid går sammen, holder heller ikke alltid stikk. 22. juli-kommisjonen ble betraktet som grundig, autoritativ og «upartisk», på tross av - og trolig dels på grunn av - at fagorganisasjonene i sektoren og sentrale berørte departementer ikke var med. "Den vet best hvor skoen trykker som har den på», heter det. Andre ganger kan partsinvolvering etterlate et inntrykk av at «bukken får passe havresekken».

\section{Hinsides NOU-ene?}

Andre kriterier som en god utredning bør oppfylle kunne nevnes, og dette er ikke ment å være uttømmende eller endelig konkluderende, men et bidrag til diskusjon av noe jeg mener er viktig, og viktigere enn mye annet vi diskuterer. Jeg får av og til høre at innfallsvinkelen min her er lett utdatert, i den forstand at antallet NOU-er som leveres årlig har gått ned. Vi ser samtidig økt bruk av "andre utvalg», gjerne mer hurtigarbeidende og med strammere mandater, og en sterkere stilling for nye aktører på utredningsmarkedet, som kunnskapssentre, tenketanker og konsulentselskaper.

Til dette er det i hvert fall to ting å si. For det første: Det leveres færre, men fortsatt mange NOU-er her til lands. Ikke minst gjøres fremdeles en rekke av de viktigste utredningene via NOU-instituttet, og vi bør snakke om hva vi mener om dem. For det andre: I en tid der utredningsregimet vårt er $i$ endring og nye trender viser seg, er det knapt blitt mindre presserende å drøfte hva slags utredning av offentlig politikk vi ønsker oss. Etter noen år med mye NOU-lesing, er mitt generelle inntrykk at NOU-systemet slett ikke alltid, men på sitt beste, leverer særdeles respektabelt i et landskap av hårete mål og vriene målkonflikter. Hvis vi skifter spor, bør vi sørge for at det NOU-ene eventuelt erstattes med, gir oss noe like bra eller bedre.

\section{Referanser}

NOU 1999: 27 "Ytringsfrihed bør finde Sted" - Forslag til ny Grunnlov § 100 NOU 2011: 7 Velferd og migrasjon: Den norske modellens framtid 
NOU 2011: 18 Struktur for likestilling

NOU 2012: 14 Rapport fra 22. juli-kommisjonen

NOU 2014: 13 Kapitalbeskatning i en internasjonal økonomi

NOU 2017: 2 Integrasjon og tillit - Langsiktige konsekvenser av høy innvandring

NOU 2017: 6 Offentlig st $\varnothing$ tte til barnefamiliene

NOU 2018: 5 Kapital i omstillingens tid - Næringslivets tilgang til kapital

NOU 2019: 3 Nye sjanser - bedre læring. Kjønnsforskjeller i skoleprestasjoner og utdanningsløp

Ryymin, Teemu (2017): Historie og politikk. Historiebruk i norsk politikkutforming etter 1945. Oslo: Universitetsforlaget.

Wolff, Jonathan (2019): Ethics and Public Policy. A Philosophical Inquiry. London: Routledge.

\footnotetext{
${ }^{1}$ Utgangspunktet for denne kommentaren er forskningsprosjektet Expertization of public inquiry commissions (2016-20) finansiert av Norges forskningsråd, se https://www.sv.uio.no/arena/english/research/projects/eurex/index.html

2 Jeg er med og gransker striden rundt «gutteproblemet i skolen» under prosjektet Determined to succeed? Maturation, motivation and gender gaps in education achievement (2019-22) finansiert av Norges forskningsråd.

${ }^{3}$ Se også den nye Utredningsinstruksen: https://www.regjeringen.no/no/dokumenter/instruks-om-utredningav-statlige-tiltak-utredningsinstruksen/id2476518/

${ }^{4}$ Jeg holder på med en studie av narkotikapolitikk under forskningssenteret PROMENTA (2019-29) finansiert av Norges forskningsråd.
} 